\title{
PROTOTYPE PENJEMUR PAKAIAN OTOMATIS BERBASIS MICROCONTROLLER ARDUINO DENGAN METODE NAÏVE BAYES SERTA MENGGUNAKAN SENSOR LDR DAN SENSOR KELEMBABAN UDARA DHT 11
}

\author{
Novan Satria Yogaswara ${ }^{1)}$, Go Frendi Gunawan ${ }^{1)}$, Febry Eka Purwiantono ${ }^{2)}$ \\ ${ }^{1}$ Teknik Informatika, Sekolah Tinggi Informatika dan Komputer Indonesia \\ ${ }^{2}$ Manajemen Informatika, Sekolah Tinggi Informatika dan Komputer Indonesia \\ ${ }^{1,2}$ Jl. Tidar Selatan No.100, Karangbesuki, Sukun, Kota Malang, Jawa Timur 65149 \\ Email:1141111049@mhs.stiki.ac.id, ${ }^{2}$ frendi@stiki.ac.id, ${ }^{3}$ febry@stiki.ac.id
}

\begin{abstract}
Abstrak
Pada perkembangan teknologi sekarang, khususnya di bidang microcontroller arduino telah banyak menciptakan berbagai macam project yang dapat menyelesaikan permasalahan dalam kehidupan seharihari. Kemudian microcontroller arduino, menjadi salah satu pilihan solusi yang ada pada saat ini. Seperti permasalahan yang diangkat pada penelitian ini. Ketika terjadi cuaca tidak menentu dan diharuskan setiap hari untuk mencuci pakaian kemudian menjemur di area terbuka, maka akan sangat merepotkan apabila terjadi hujan. Oleh karena itu diperlukan peran teknologi microcontroller untuk membantu menyelesaikan permasalahan yang tersebut. Yakni dengan cara membuat penjemur pakaian otomatis yang berbasis microcontroller arduino, serta penambahan metode Nä̈ve Bayes yang dapat menghitung klasifikasi data yang berisi nilai intensitas cahaya dan kelembapan udara. Data tersebut diperoleh dari hasil pengambilan selama 1 minggu dengan kondisi cuaca yang tidak menentu. Data tersebut akan membantu dalam proses pengambilan keputusan pada motor penggerak yang digunakan. Penjemur pakaian akan bergerak keluar dan kedalam sesuai dengan perintah yang telah diproses hitung dengan menggunakan metode Nä̈ve Bayes pada arduino. Hasilnya algoritma Naive Bayes mampu memberikan keputusan $100 \%$ akurat bila dibandingkan dengan algoritma iflelse yang hanya menghasilkan $50 \%$ keputusan akurat. Diharapkan dengan adanya penjemur pakaian otomatis ini, akan menjadi solusi dari permasalahan yang ada pada saat ini.
\end{abstract}

Kata Kunci: arduino, microcontroller, nä̈ve bayes, sensor LDR, sensor DHT 11

\section{Pendahuluan}

Perkembangan teknologi yang cepat dan didukung dengan Sumber Daya Manusia (SDM) yang memiliki inovasi, sehingga membuat manusia berlomba lomba menciptakan alat yang dapat mempermudah pekerjaan manusia. Salah satu cara yang dirasa tepat untuk mempermudah pekerjaan manusia adalah dengan menggunakan microcontroller. Menurut [1], microcontroller adalah suatu IC dengan kepadatan yang sangat tinggi, dimana semua bagian yang diperlukan untuk suatu kontroler sudah dikemas dalam satu keping, biasanya terdiri dari CPU (Central Processing Unit), RAM (Random Access Memori), EEPROM/EPROM/ PROM/ROM, I/O, Serial \& Parallel, Timer, Interupt Controller. Sedangkan menurut [2], microcontroller adalah sebuah chip yang berfungsi sebagai pengontrol rangkaian elektronik dan umunya dapat menyimpan program didalamnya. Program pada microcontroller menginstruksikan komputer untuk melakukan jalinan yang panjang dari aksi-aksi sederhana untuk melakukan tugas yang lebih komplek yang diinginkan oleh programmer.

Penggunaan media berupa simulasi untuk memberikan gambaran pada alat. Menurut [3], simulasi adalah sebagai suatu model sistem dimana komponennya di presentasikan oleh prosesor-prosesor aritmatika dan logika yang di jalankan komputer untuk memperkirakan sifat-sifat dinamis sistem tersebut. Sedangkan menurut [4], simulasi adalah merupakan proses perencanaan model dari sistem nyata yang dilanjutkan dengan pelaksanaan eksperimen terhadap model untuk mempelajari perilaku sistem atau evaluasi strategi. Sehingga dapat ditarik kesimpulan bahwa simulasi merupakan model dari sebuah sistem yang digunakan sebelum diaplikasikan ke sistem nyata untuk mengetahui pola yang terjadi.

Salah satu permasalahan yang ada pada masyarakat saat ini, ketika sedang melakukan penjemuran pakaian di saat cuaca yang tidak menentu dan kemudian mengharuskan meninggalkan rumah sendiri karena ada urusan pekerjaan. Hal ini akan membuat gelisah, karena takut terkena air hujan ketika hujan datang dan pakaian dalam kondisi terjemur di luar, sehingga akan membutuhkan waktu yang cukup lama untuk kembali menjemur pakaian. Permasalahan diatas dapat diselesaikan dengan bantuan microcontroller.

Pemecahan masalah tersebut, pernah diangkat dalam sebuah jurnal dengan judul Prototype Jemuran Otomatis Berbasis Arduino MEGA 2560 [5] yang membahas mengenai penjemuran pakaian otomatis berbasis microcontroller. Pada jurnal tersebut masih terdapat kekurangan dalam hal, cara kerja dan perintah algoritma yang masih kurang tepat, seperti yang telah dibahas pada jurnal tersebut, bahwa penggunaan dari 
dua sensor yang digunakan pada penjemur pakaian otomatis dirasa kurang dimaksimalkan fungsinya karena jika salah satu sensor mendeteksi adanya indikasi akan datangnya hujan atau pada sensor LDR (Light Dependent Resistor) tertutup benda asing maka penjemur pakaian otomatis ini akan langsung bekerja tanpa menunggu data tambahan dari sensor yang lain, hal ini akan membuat kerja dari penjemur pakaian otomatis menjadi kurang maksimal dan data yang diterima arduino menjadi kurang valid.

Dapat dikatakan bahwa penggunaan dua sensor pada penelitian tersebut, tidak saling melengkapi dalam pemberian data terhadap arduino. Pada penelitian tersebut dijelaskan bahwa sensor hujan yang dibuat secara manual memiliki kekurangan yaitu kondisi akan selalu terbaca basah sampai kondisi sensor benar-benar kering sehingga penggunaan sensor seperti ini kurang optimal. Dari beberapa kekurangan pada jurnal tersebut, dapat dijadikan acuan untuk membuat penjemur pakaian otomatis yang lebih baik serta memiliki kelebihan dari yang ada sebelumnya. Sensor adalah suatu peralatan yang berfungsi untuk mendeteksi gejala-gejala atau sinyal-sinyal yang berasal dari perubahan suatu energi seperti energi listrik, energi fisika, energi kimia, energi biologi, energi mekanik dan sebagainya [6].

Dari kekurangan dan saran yang ada pada jurnal, dapat dibuat simulasi penjemur pakaian otomatis dengan basis arduino menggunakan sensor cahaya dan sensor kelembapan udara. Dua sensor ini akan memberikan data yang lebih akurat dibandingkan dengan penggunaan sensor yang telah ada pada jurnal sebelumnya. Karena pada penjemur pakaian otomatis ini, akan memaksimalkan kerja dari dua sensor dengan bantuan algoritma yang tepat melalui arduino IDE yang akan memberikan perintah selanjutnya, sehingga dua sensor ini akan saling melengkapi dalam penyajian data. Penggunaan flowchart digunakan untuk menerangkan program yang berjalan. Bagan alir (flowchart) adalah bagan (chart) yang menunjukkan alir atau arus (flow) di dalam program atau prosedur sistem secara logika [7]. Dapat disimpulkan bahwa flowchart adalah gambaran umum yang menjelaskan alur dari sebuah sistem dengan menggunakan simbolsimbol sebagai suatu informasi.

Kelebihan dengan mengunakan sensor LDR dan sensor DHT 11, yakni dapat membantu memasukkan penjemur pakaian secara otomatis sebelum pakaian terkena air hujan. Serta penggunaan sensor yang lebih baik dari sebelumnya, dan penambahan cara perhitungan dengan menggunakan metode Nä̈ve Bayes untuk mempermudah perhitungan. sehingga kerja dari penjemur pakaian otomatis ini akan menjadi lebih baik. Penjemur pakaian otomatis ini, akan sangat diperlukan untuk membantu mengatasi permasalahan pada saat menjemur pakaian.

\section{Metode}

Arduino merupakan sebuah perangkat yang terdiri dari beberapa komponen. Pada Arduino terdapat sebuah microcontroller yang berfungsi untuk mengerjakan perintah-perintah yang masuk, kemudian diteruskan ke dalam sebuah perangkat keras (hardware) [8]. Microcontroller tersebut, terletak di dalam board Arduino beserta komponen elektro yang lain. Sehingga dapat dijelaskan bahwa Arduino adalah alat pengendali komponen mikro yang bersifat open source, diturunkan dari wiring platform, dirancang untuk memudahkan penggunaan elektronik dalam berbagai bidang. Disamping itu Arduino sudah banyak dipakai untuk pemecahan masalah yang ada pada kehidupan seharihari dengan menerapkan simulasi. Hardware yang ada pada Arduino memiliki prosesor Atmel AVR dan software yang digunakan memiliki bahasa pemrograman sendiri. Pada implementasinya pada penjemur pakaian otomatis, digunakan algoritma tambahan berupa metode Nä̈ve Bayes. Metode inii, dapat memberikan hasil yang akurat pada setiap keputusannya.

Metode Nä̈ve Bayes merupakan pengklasifikasian dengan metode probabilitas dan statistik [9] yang mana untuk setiap kelas keputusan, dihitung probabilitas dengan syarat bahwa kelas keputusan adalah benar, mengingat vektor informasi obyek. Algoritma ini mengasumsikan bahwa atribut obyek adalah independen. Probabilitas yang terlibat dalam memproduksi perkiraan akhir dihitung sebagai jumlah frekuensi dari "master" tabel keputusan. Keuntungan dari penggunaan metode Nä̈ve Bayes adalah bahwa metode ini, hanya membutuhkan jumlah data pelatihan (training data) yang kecil untuk menentukan estimasi parameter yang diperlukan dalam proses pengklasifikasian. Karena telah diasumsikan sebagai variabel independent, sehingga hanya varian dari suatu variabel dalam sebuah kelas yang dibutuhkan untuk menentukan klasifikasi, bukan keseluruhan dari matriks kovarians [10]. Pada metode Nä̈ve Bayes terdapat beberapa tahapan pengerjaan yaitu:

- $\quad$ Menghitung jumlah kelas/label.

- Menghitung jumlah kasus per kelas

- Kalikan semua variable kelas

- Bandingkan hasil per kelas

Penggunaan metode Nä̈ve Bayes digunakan untuk membantu perhitungan pada penjemur pakaian otomatis. Mengalikan hasil dari probabilitas kelas dengan hasil dari setiap kelas yang sama. Kemudian dicari probabilitas yang paling besar. Pengklasifikasi Bayesian memiliki tingkat kesalahan minimal dibandingkan dengan klasifikasi lainnya. Namun, dalam prakteknya hal ini tidak selalu terjadi, karena ketidakakuratan asumsi yang dibuat untuk penggunaannya, seperti kondisi kelas independen dan kurangnya data probabilitas yang tersedia. Pengklasifikasi Bayesian juga berguna dalam memberikan pembenaran teoritis untuk pengklasifikasi lain yang tidak secara eksplisit menggunakan teorema Bayes.

Penelitian ini, melakukan pengembangan dari beberapa jurnal, dengan melakukan implementasi pada saran-saran jurnal yang dapat membantu untuk melakukan pengembangan alat. Pada jurnal tersebut 
terdapat saran yang mengatakan bahwa kerja dari sensor air dan sensor intensitas cahaya belum dapat bekerja secara bersamaan dan algoritma dalam alat yang lama, terdapat kekurangan dalam ketepatan dalam mengambil keputusan. Sehingga peneliti mengembangkan alat sehingga dapat bekerja secara tepat dan maksimal.

Pada pembuatan penjemur pakaian otomatis ini, diperlukan alur urutan pengerjaan, sehingga dapat dilakukan langkah-langkah untuk memulai perancangan sampai implementasi pada pembuatan alat. Alur urutan tersebut dapat dilihat pada Gambar 1.

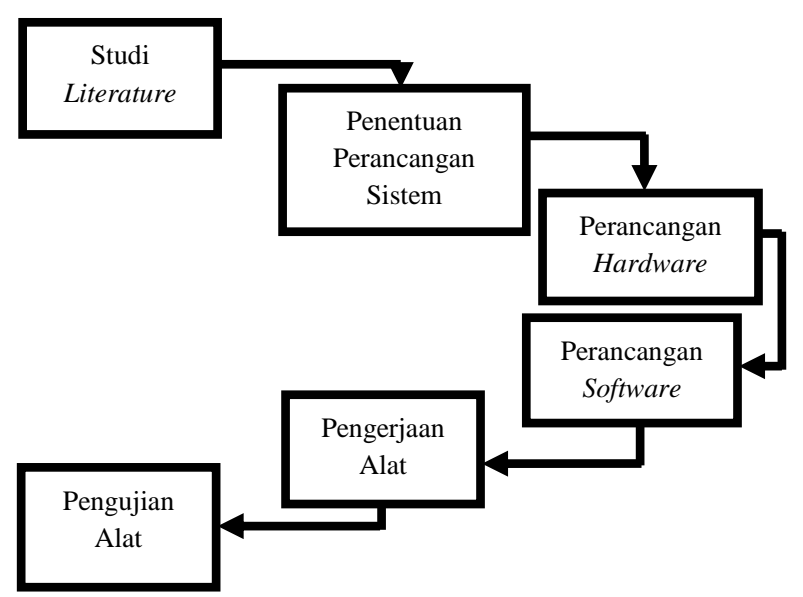

Gambar 1. Alur Urutan Penelitian

\section{Hasil dan Pembahasan}

Pada tahap implementasi pada Arduino UNO, dapat dilakukan dengan melakukan pengerjaan perakitan alat dan komponen sesuai dengan desain yang sudah dilakukan tahap perancangan. Berikut adalah tahapantahapan yang dilakukan pada saat perancangan :

1) Hubungkan power dengan papan breadboard, diperuntukkan sebagai daya utama dari keseluruhan komponen dan 2 motor servo karena motor servo memiliki daya sendiri yang lebih besar dengan menggunakan adaptor.

2) Hubungkan 2 motor servo yang memiliki torsi 13 $\mathrm{kg} / \mathrm{cm}$ dengan papan breadboard, diperuntukkan sebagai penghubung antara motor servo dengan arduino. Masing-masing motor servo memiliki 3 pin penghubung yaitu : VCC $5 \mathrm{~V}$, GND, Transfer Data (Pulse).

3) Hubungkan modul SD card dengan papan breadboard, diperuntukkan sebagai penyimpan data logger pada perhitungan Nä̈ve Bayes di arduino. Modul SD card terdiri dari 6 pin penghubung yaitu : VCC 5 V, GND, MISO, MOSI, SCK, CS.

4) Hubungkan LCD dengan papan breadboard, diperuntukkan sebagai pemberian informasi terhadap pengguna mengenai hasil perhitungan ataupun informasi yang lain. LCD terdiri dari 16 pin penghubung yang tergolong banyak, yaitu : VSS, VDD, VO, RS, R_W, E, DB0, DB1, DB2, DB3, DB4, DB5, DB6, DB7, A, K.
5) Hubungkan potentiometer dengan papan breadboard dan pin pada LCD, diperuntukkan sebagai pengatur intensitas cahaya pada layar LCD. Potentiometer terdiri dari 3 pin penghubung yaitu : A, U3, E.

6) Tancapkan sensor LDR pada papan breadboard kemudian berikan 2 kabel penghubung ke arduino dan berikan resistor pada pin VCC $5 \mathrm{~V}$ yang berhubungan dengan arduino. Sensor LDR diperuntukkan sebagai penerima intensitas cahaya pada ruangan sekitar kemudian diteruskan kepada arduino. Sensor LDR terdiri dari 2 pin yaitu : pin 0 (GND) dan pin 1 (VCC 5 V).

7) Tancapkan sensor DHT 11 pada papan breadboard kemudian berikan 3 kabel penghubung ke arduino dan berikan resistor pada pin VCC $5 \mathrm{~V}$ yang berhubungan dengan arduino. Sensor DHT 11 diperuntukkan sebagai penerima kelembaban udara pada ruangan sekitar kemudian diteruskan kepada arduino. Sensor DHT 11 terdiri 3 pin yaitu: VCC 5 V, Data Signal, GND.

8) Hubungkan papan arduino dengan papan breadboard guna mengontrol semua komponen yang telah dirangkai. Arduino diperuntukkan sebagai otak dari penjemur pakaian otomatis yang menggunakan metode Nä̈ve Bayes. Arduino dihubungkan pada VCC $5 \mathrm{~V}$ dan GND yang telah di setting pada papan breadboard.

Tahap pengujian alat penjemur pakaian otomatis dengan menggunakan metode Nä̈ve Bayes, di lakukan untuk mengetahui cara kerja alat yang telah dibuat. Pada tahap pengujian dibagi menjadi 3 kategori pengujian:

\subsection{Pengujian Dalam Ruangan dengan Bantuan Lampu dan Tisu Basah sebagai Alat Bantu Pengujian}

Pada tahap pengujian dalam ruangan, diperlukan alat penunjang tambahan berupa lampu dan tisu basah sebagai pengganti keadaan alam. Pengujian di dalam ruangan tersebut dilakukan untuk mencari tahu hasil uji dari penjemur pakaian otomatis yang di berikan lampu dan tisu basah sebagai pengganti kondisi alam di luar ruangan. Hasil pengujian dapat diperhatikan pada Gambar 2.

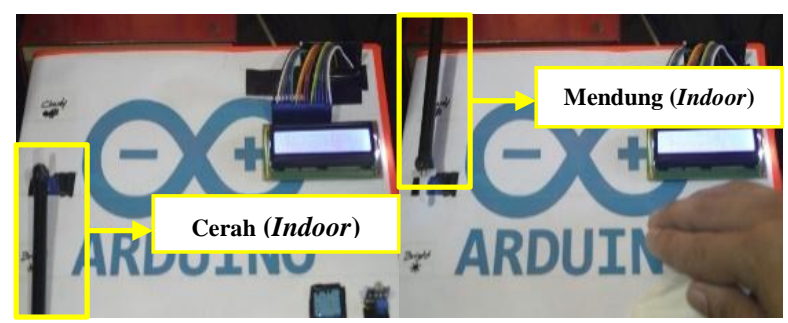

Gambar 2. Pengujian Tidak atau dengan Menggunakan Lampu dan Tisu Basah

Tabel 1 menunjukkan hasil dari pengujian dengan menggunakan lampu dan tisu basah. 
Tabel 1. Hasil Pengujian dengan Lampu dan Tisu Basah

\begin{tabular}{ccccc}
\hline No & LDR & DHT 11 & Hasil & $\begin{array}{c}\text { Motor } \\
\text { Servo }\end{array}$ \\
\hline 1 & $65 f c$ & $45 \%$ & Mendung & Masuk \\
2 & $107 f c$ & $44 \%$ & Mendung & Masuk \\
3 & $74 f c$ & $47 \%$ & Mendung & Masuk \\
4 & $2019 f c$ & $42 \%$ & Cerah & Keluar \\
5 & $3013 f c$ & $43 \%$ & Cerah & Keluar \\
\hline
\end{tabular}

Sumber: Hasil Penelitian (2018)

Penggunaan alat bantu tambahan berupa tisu basah dan lampu dapat digunakan untuk meningkatkan nilai kelembaban dan intensitas cahaya sebagai pengganti kondisi alam pada pengujian indoor. Sedangkan jika menggunakan tangan sebagai penutup sensor LDR dapat menurunkan nilai intensitas cahaya. Dengan demikian output untuk pergerakan motor dapat sesuai dengan perhitungan metode Nä̈ve Bayes yang ada pada arduino.

\subsection{Pengujian Luar Ruangan (Tempat Terbuka) Sesuai dengan Kondisi Alam pada saat Pengujian}

Pada tahap pengujian luar ruangan, alat penjemur pakaian otomatis akan diletakkan di luar ruangan dengan kondisi alam yang ada. Pengujian tersebut dilakukan untuk mengetahui tingkat keberhasilan penjemur pakaian otomatis pada saat berada di luar ruangan. Hasil pengujian dapat dilihat pada Gambar 3.

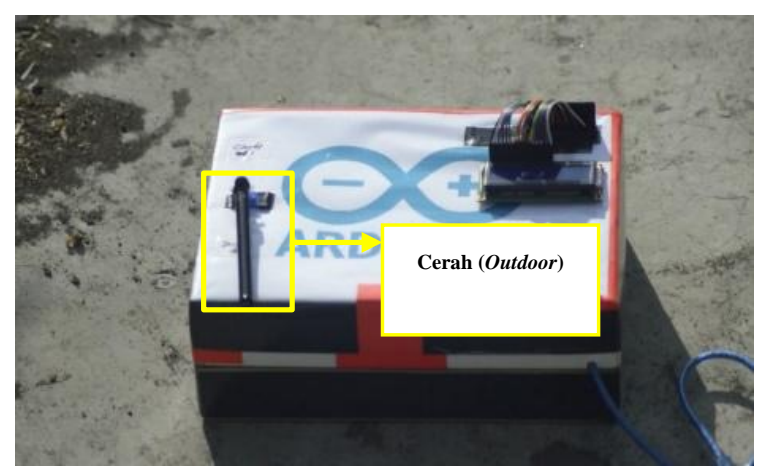

Gambar 3. Pengujian di Luar Ruangan

Penggunaan metode Nä̈ve Bayes pada pembuatan penjemur pakaian otomatis difungsikan untuk mempermudah cara kerja penjemur pakaian otomatis dari sisi perancangan software. Metode Nä̈ve Bayes dapat menghitung dengan tepat berdasarkan penyajian data. Adapun data yang diambil berdasarkan 2 parameter yang digunakan dapat dilihat pada Tabel 2.

Tabel 2. Pengambilan Data

\begin{tabular}{cccc}
\hline No & $\begin{array}{c}\text { Intensitas } \\
\text { Cahaya }(\text { lux })\end{array}$ & $\begin{array}{c}\text { Kelembaban } \\
\text { Udara }(\%)\end{array}$ & $\begin{array}{c}\text { Class } \\
(\text { Output })\end{array}$ \\
\hline 1 & 4645 & 56 & Cerah \\
2 & 4645 & 53 & Cerah \\
3 & 220 & 57 & Mendung \\
4 & 194 & 58 & Mendung \\
5 & 0 & 52 & Mendung \\
6 & 1346 & 46 & Cerah
\end{tabular}

\section{3}

801

907

956

874

678

4645

4630

4645

4645

4645

4645

4640

4645

4535

4640

4645

1347

1347

4645

3600

4645

3600

1296

1296

2576

4645

801

1347

1261

907

1261

1190

962

988

962

1403

1392

4645

1351

4265

4645

1313

4643
Cerah

Mendung

Mendung

Mendung

Mendung

Mendung

Cerah

Cerah

Cerah

Cerah

Cerah

Cerah

Cerah

Cerah

Cerah

Cerah

Cerah

Mendung

Mendung

Cerah

Cerah

Cerah

Cerah

Mendung

Mendung

Mendung

Cerah

Mendung

Mendung

Mendung

Mendung

Mendung

Mendung

Mendung

Mendung

Mendung

Mendung

Mendung

Cerah

Mendung

Cerah

Cerah

Mendung Cerah

Sumber: Hasil Penelitian (2018)

Berikut ini adalah penjelasan dari data latih pada Tabel 2:

- Data diambil setiap 1 jam dengan pengambilan sejumlah 4 data/jam.

- 1 jam nya dibagi menjadi 4 bagian, sehingga 1 data per 15 menit.

- Data diambil pada saat cuaca berubah ubah pada 3 hari pengambilan.

- Pengambialan dilakukan pada jam 06.00; 07.00; 08.00; 09.00 (Pada hari ke 1); 10.00; 11.00; $12.00 ; 13.00$ (Pada hari ke 2); 14.00; 15.00; 16.00; 17.00 (Pada hari ke 3) (WIB).

- Intensitas Cahaya $=f c($ Foot Candle $)$.

- Kelembapan Udara $=\%$ (Percent $)$. 
Di bawah ini adalah rumus umum pada algoritma Nä̈ve Bayes:

$$
P(C \mid X)=\frac{P(X \mid C) p(C)}{P(X)}
$$

Pada perancangan algoritma dari penjemur pakaian otomatis, yang menggunakan penerapan dari metode Nä̈ve Bayes yang dirasa dapat membantu dalam perhitungan pada arduino secara tepat sesuai data pasti dari hasil pengambilan secara langsung. Sebelum diproses, data pada tabel dijadikan tabel kumulatif dengan rentang yang disesuaikan dengan kebutuhan sehingga dapat mempermudah pekerjaan. Tabel 3 menunjukkan hasil dari perhitungan kumulatif parameter intensitas cahaya.

Tabel 3. Hasil Perhitungan Kumulatif Intensitas Cahaya

\begin{tabular}{cccc}
\hline No & Intensitas Cahaya $(\boldsymbol{f} \boldsymbol{c})$ & Mendung & Cerah \\
\hline 1 & $0-1161.5$ & 12 & 2 \\
2 & $1161.5-2323.5$ & 9 & 2 \\
3 & $2323.5-3485.5$ & 1 & 3 \\
4 & $3485.5-4647.5$ & 3 & 18 \\
\hline & & \multicolumn{2}{c}{ Total =50 } \\
\hline
\end{tabular}

Sumber: Hasil Penelitian (2018)

Sedangkan untuk hasil dari perhitungan kumulatif parameter kelembaban udara dapat dilihat pada Tabel 4.

Tabel 4. Hasil Perhitungan Kumulatif Kelembaban Udara

\begin{tabular}{cccc}
\hline No & $\begin{array}{c}\text { Kelembaban Udara } \\
(\boldsymbol{\%})\end{array}$ & Mendung & Cerah \\
\hline 1 & $39.5-44.5$ & 2 & 4 \\
2 & $44.5-49.5$ & 15 & 14 \\
3 & $49.5-54.5$ & 7 & 5 \\
4 & $54.5-59.5$ & 2 & 1 \\
\hline & \multicolumn{2}{c}{ Total $=\mathbf{5 0}$} \\
\hline
\end{tabular}

Sumber: Hasil Penelitian (2018)

\section{Contoh Pengerjaan}

Data yang di Cari

Data percobaan: (Intensitas Cahaya $=4645.0$ | Kelembapan Udara $=47.1$ )

$\mathrm{P}(\mathrm{Ci})$

\section{Langkah 1}

$\mathrm{P}($ Class $=$ "Cerah" $)=24 / 50=0.48$

$\mathrm{P}($ Class $=$ "Mendung" $)=26 / 50=0.52$

\section{Langkah 2}

$\mathrm{P}(\mathrm{X} \mid \mathrm{Ci})$

$\mathrm{P}$ (Intensitas cahaya $=$ "4645.0" $\mid$ Class $=$ "Cerah")

$=18 / 24=0.75$

$\mathrm{P}$ (Intensitas cahaya = "4645.0" | Class = "Mendung")

$=3 / 26=0.11$

P (Kelembapan udara $=$ "47.1" | Class = "Cerah")

$=14 / 24=0.58$
$\mathrm{P}$ (Kelembapan udara $=$ "47.1" | Class $=$ "Mendung") $=15 / 26=0.57$

Langkah 3

$\mathrm{P}(\mathrm{X} \mid$ Class $=$ "Cerah") $=0.75 \times 0.58=0.435$

$\mathrm{P}(\mathrm{X} \mid$ Class $=$ "Mendung" $)=0.11 \times 0.57=0.063$

Langkah 4

$\mathrm{P}(\mathrm{X} \mid \mathrm{Ci}) \times \mathrm{P}(\mathrm{Ci})$

$\mathrm{P}(\mathrm{X} \mid$ Class $=$ "Cerah") $\times \mathrm{P}($ Class $=$ "Cerah")

$0.48 \times 0.435=0.209$

$\mathrm{P}(\mathrm{X} \mid$ Class="Mendung" $)$ x $\mathrm{P}($ Class=Mendung")

$0.52 \times 0.063=0.033$

Untuk data (Intensitas Cahaya $=4645.0$ Kelembapan Udara $=$ 47.1) diperoleh hasil perhitungan dengan metode Nä̈ve Bayes, bahwa data pada percobaan tersebut memberikan perintah Keluar kepada penjemur pakaian otomatis. Karena perhitungan class Cerah lebih besar dari class Mendung.

Pada Tabel 5 menunjukkan hasil dari pengujian di luar ruangan (tempat terbuka). Pengujian ini dilakukan untuk mengetahui tingkat ketepatan hasil keputusan dari perhitungan metode dan cara kerja alat pada kondisi alam yang sesungguhnya.

Tabel 5. Hasil Pengujian di Luar Ruangan (Tempat

\begin{tabular}{ccccc}
\multicolumn{5}{c}{ Terbuka) } \\
\hline No & LDR & DHT 11 & Hasil & Motor \\
\hline 1 & $4457 \mathrm{fc}$ & $42 \%$ & Cerah & Keluar \\
2 & $4407 \mathrm{fc}$ & $42 \%$ & Cerah & Keluar \\
3 & $4411 \mathrm{fc}$ & $42 \%$ & Cerah & Keluar \\
4 & $3016 \mathrm{fc}$ & $42 \%$ & Cerah & Keluar \\
5 & $4448 \mathrm{fc}$ & $42 \%$ & Cerah & Keluar \\
\hline \multicolumn{5}{l}{ Sumber: Hasil Penelitian (2018) }
\end{tabular}

Pada Tabel 5 kondisi pengujian alat yaitu pada saat jam 08.00 WIB pagi, dan kondisi pada saat itu cerah yang dilakukan pada tanggal 26 Oktober 2018.

\subsection{Hasil Perbandingan Algoritma Penjemur Otomatis}

Setelah melakukan perakitan alat serta pembuatan sketch arduino dan serangkaian pengujian dasar sebelumnya, maka untuk membuktikan bahwa penjemur pakaian otomatis dengan menggunakan metode Nä̈ve Bayes memiliki keunggulan dari penjemur otomatis yang lama, dapat dilakukan pengujian dengan membandingkan cara kerja penjemur pakaian otomatis lama (tanpa metode) dengan yang baru (pakai metode). Perbandingan tersebut, dilakukan dengan menggunakan microsoft excel dengan rumus, data latih dan langkah-langkah perhitungan yang sama pada sketch (program) di arduino penjemur pakaian otomatis, hal ini dilakukan untuk memberikan hasil berupa data yang valid. Pada Tabel 6 merupakan hasil dari perbandingan penjemur pakaian otomatis lama dengan penjemur pakaian otomatis baru. 
Tabel 6. Hasil Perbandingan Algoritma Penjemur Pakaian Otomatis Lama dengan Baru

\begin{tabular}{|c|c|c|c|c|c|}
\hline \multirow[b]{2}{*}{ No } & \multirow[b]{2}{*}{$\begin{array}{c}\text { LDR } \\
(f c)\end{array}$} & \multirow[b]{2}{*}{$\begin{array}{c}\text { DHT } \\
11 \\
(\%)\end{array}$} & \multirow{2}{*}{$\begin{array}{c}\text { Kondisi } \\
\text { Cerah/ } \\
\text { Mendung }\end{array}$} & \multicolumn{2}{|c|}{ Algoritma } \\
\hline & & & & $\begin{array}{c}\text { Lama } \\
\text { (if/else) }\end{array}$ & $\begin{array}{c}\text { Baru } \\
\text { (Nä̈ve } \\
\text { Bayes) }\end{array}$ \\
\hline 1 & 4443 & 42 & Cerah & Keluar & Keluar \\
\hline 2 & 903 & 52 & Mendung & Keluar & Masuk \\
\hline 3 & 3713 & 43 & Cerah & Keluar & Keluar \\
\hline 4 & 44 & 51 & Mendung & Masuk & Masuk \\
\hline 5 & 2819 & 43 & Cerah & Keluar & Keluar \\
\hline 6 & 174 & 53 & Mendung & Masuk & Masuk \\
\hline 7 & 4351 & 42 & Cerah & Keluar & Keluar \\
\hline 8 & 1954 & 45 & Mendung & Keluar & Masuk \\
\hline 9 & 679 & 47 & Mendung & Keluar & Masuk \\
\hline 10 & 1011 & 45 & Mendung & Keluar & Masuk \\
\hline 11 & 2573 & 49 & $\mathrm{Hjn} / \mathrm{Pns}$ & Keluar & Masuk \\
\hline 12 & 356 & 47 & Mendung & Keluar & Masuk \\
\hline 13 & 3817 & 42 & Cerah & Keluar & Keluar \\
\hline 14 & 28 & 49 & Mendung & Keluar & Masuk \\
\hline 15 & 1119 & 45 & Mendung & Keluar & Masuk \\
\hline 16 & 4119 & 42 & Cerah & Keluar & Keluar \\
\hline 17 & 33 & 45 & Mendung & Keluar & Masuk \\
\hline 18 & 28 & 43 & Mendung & Keluar & Masuk \\
\hline 19 & 4402 & 42 & Cerah & Keluar & Keluar \\
\hline 20 & 3574 & 43 & Cerah & Keluar & Keluar \\
\hline
\end{tabular}

Sumber: Hasil Penelitian (2018)

Dari hasil perbandingan antara algoritma penjemur pakaian otomatis yang lama dengan algoritma penjemur pakaian otomatis baru dapat disimpulkan bahwa algoritma if/else memiliki hasil keputusan salah sebanyak 10 dan tepat sebanyak 10 dari 20 data latih kemudian algoritma Naïve Bayes memiliki hasil keputusan salah 0 dan benar sebanyak 20 dari 20 data latih. Dari hasil tersebut dapat dibuat dalam bentuk persentase keseluruhan. Persentase pada algoritma ditunjukkan pada Tabel 7.

Tabel 7. Hasil Perbandingan Algoritma Penjemur Pakaian Otomatis Lama dengan Baru

\begin{tabular}{|c|c|c|c|}
\hline No & Algoritma & $\begin{array}{c}\text { Persentase } \\
\text { Akurasi }\end{array}$ & Keterangan \\
\hline 1 & Iflelse & $50 \%$ & $\begin{array}{l}\text { Kurang } \\
\text { Akurat }\end{array}$ \\
\hline 2 & $\begin{array}{l}\text { Metode } \\
\text { Nä̈ve } \\
\text { Bayes }\end{array}$ & $100 \%$ & Akurat \\
\hline
\end{tabular}

Sumber: Hasil Penelitian (2018)

Di bawah ini adalah penjelasan mengenai data yang ada pada Tabel 6:

- Data latih intensitas cahaya dan kelembapan udara diambil dari perolehan sensor LDR dan DHT 11.

- Kondisi, menjelaskan keadaan cuaca (saat itu) yang ada pada pengambilan data latih.

- Perhitungan yang dilakukan pada kolom program/algoritma lama, dibuat sama dengan langkah-langkah perhitungan pada sketch arduino penjemur pakaian otomatis lama.
- Perhitungan yang dilakukan pada kolom program/algoritma baru dengan metode Nä̈ve Bayes, dibuat sama dengan langkah-langkah perhitungan pada sketch arduino penjemur pakaian otomatis baru.

- Tulisan berwarna merah, menandakan bahwa hasil akhir dari perhitungan tidak sesuai dengan kondisi pada saat itu (pengambilan data latih).

\section{Kesimpulan}

Perkembangan serta kemajuan teknologi microcontroller telah dapat membantu menciptakan solusi bagi kehidupan sehari-hari. Pada kasus ini penulis membuat solusi dengan membuat penjemur pakaian otomatis dengan menggunakan metode Nä̈ve Bayes dan penambahan sensor LDR serta sensor DHT 11. Kesimpulan yang dapat diambil dari penelitian pembuatan alat penjemur pakaian otomatis dengan menggunakan metode Nä̈ve Bayes yaitu perhitungan Naïve Bayes dapat membantu dalam penyelesaian hasil akhir dari pengujian penjemur pakaian otomatis dengan menggunakan data latih yang ada dan sesuai dengan perhitungan manual.

Setelah melakukan pengujian alat di luar ruangan tanpa alat penunjang (lampu senter dan tisu basah) dan di dalam ruangan dengan bantuan alat penunjang, bahwa perhitungan Nä̈ve Bayes dapat bekerja dengan baik. Selain itu penjemur pakaian otomatis dengan menggunakan metode Nä̈ve Bayes dapat bekerja lebih baik dari penjemur pakaian otomatis lama (tanpa metode), karena memiliki algoritma yang dapat menghitung dan memberikan hasil lebih akurat.

Penjemur pakaian otomatis dengan menggunakan metode Naïve Bayes ini dapat dikembangkan sehingga dapat menyimpan data baru yang diperoleh dari 2 sensor LDR dan DHT 11 (Input Datalogger). Perlu juga untuk menambahkan battery dengan pengisian secara otomatis dan cara kerja otomatis on jika terjadi indikasi daya listrik melemah yang akan difungsikan jika terjadi listrik padam dan akan otomatis off pada keadaan sebaliknya. Jika ingin dapat menampung pakaian dengan jumlah yang lebih berat, dapat dilakukan dengan mengganti motor servo dengan torsi yang lebih besar serta dapat menyesuaikan ulang mekanis penggerak penjemur pakaian.

\section{Daftar Pustaka}

[1] S. Setiawan, "Aplikasi Pengaman Kendaraan Berbasis Mikrokontroler Atmega 8 dan Attiny 2313," J. Techno Nusa Mandiri, 2017.

[2] F. Amani and K. Prawiroredjo, "Alat Ukur Kualitas Air Minum Dengan Parameter Ph, Suhu, Tingkat Kekeruhan, Dan Jumlah Padatan Terlarut," JETri, 2016.

[3] J. R. Emshoff, "A computer simulation model of the Prisoner's Dilemma," Behav. Sci., 1970.

[4] R. Shannon and J. D. Johannes, "Systems Simulation: The Art and Science," IEEE Trans. Syst. Man. Cybern., 1976.

[5] R. Hutabarat et al., "Prototype Jemuran Otomatis 
Berbasis Arduino Mega 2560," pp. 4-7.

[6] S. L. Padula and R. K. Kincaid, "Optimization Strategies for Sensor and Actuator Placement," Contractor, 1999.

[7] R. Prasetyo, I. Iftadi, and T. Rochman, "Perancangan Sistem Informasi Tugas Akhir dan Kerja Praktek di Jurusan Teknik Industri UNS," Performa, 2010.

[8] E. Ilham, "Pengertian dan Kelebihan Arduino," IT-Jurnal, 2015. .

[9] F. E. Purwiantono, "Model Klasifikasi Untuk Deteksi Situs Phising Di Indonesia," no. November 2017, p. 156, 2017.

[10] D. L. Olson and D. Delen, Advanced data mining techniques. 2008. 